\title{
Erratum to: Dual blockade of the renin-angiotensin system in chronic renal disease: to do or not to do
}

\author{
The editors, Clinical and Experimental Nephrology
}

Published online: 28 May 2010

(C) Japanese Society of Nephrology 2010

Erratum to: Clin Exp Nephrol (2004) 8:183-187

DOI 10.1007/s10157-004-0307-x

This article has been retracted because it cited as a major source the article "Combination treatment of angiotensin-II receptor blocker and angiotensin-converting-enzyme inhibitor in non-diabetic renal disease (COOPERATE): a randomised controlled trial", which had been retracted by The Lancet.

The editors, Clinical and Experimental Nephrology

The online version of the original article can be found under doi:10.1007/s10157-004-0307-x.

The editors, Clinical and Experimental Nephrology

The Japanese Society of Nephrology, Tokyo, Japan

e-mail: cen@springer.jp 